\title{
EMPOWERING THE ARABIC - JAVANESE TRANSLATION AS AN INDIGENOUS LANGUAGE PROTECTION IN ASIA TOWARD THE BOOKS OF ISLAMIC MORAL ETHIC
}

\author{
Muhammad Yunus Anis, Arifuddin, Eva Farhah, dan Abdul Malik
}

Arabic Literature Department, Sebelas Maret University Surakarta

\begin{abstract}
: this article was undertaken to investigate the moral ethics learned in the Arabic-Javanese translation text, and how this model of translation can be the main aspect of protecting the indigenous/natural/mother language in Indonesia as a main potential of Asian Cultural Heritage. The data of this research is a Arabic - Javanese translation texts and also some units of language inside the texts. The result of this article shows that there is a connection line between empowering of Arabic Javanese translation and protecting the indigenous language.
\end{abstract}

Keywords: Arabic Javanese translation models, Indigenous language, Asian language, the Book of Moral Ethic Bidayatul Hidayah.

\begin{abstract}
Abstrak: Tujuan penulisan penelitian ini adalah untuk memaparkan nilai moral dan etika yang didapatkan dari teks terjemahan Bahasa Arab dan Jawa, dan bagaimana hasil penerjemahan tersebut bisa menhadi aspek utama untuk menjaga keaslian bahasa ibu sebagai warisan budaya Asia. Data penelitian ini berupa teks terjemahan bahasa Jawa dan juga beberapa unit bahasa didalam teks. Hasil penelitian ini menunjukkan bahwa terdapat hubungan antara menggunakan terjemahan Bahasa Arab dan Jawa serta menjaga keaslian bahasa.
\end{abstract}

Kata-kata kunci: model terjemahan Bahasa Arab, kandungan nilai-nilai moral kitab Bidayatul Hidayah, bahasa asli

Today, the afraid of an extincting and the destroying of the indigenous language (mother language) righteously should become the major attention of Indonesian people. The extincting of the indigenous language is the the great indicator of the lost of the cultural heritage. When the eclipse of the cultural heritage was appeared, the character of the nation rubbed down. Thus, the existence of mother language must to be preserved.

The indigenous language (mother language and native language) is the first language mastered by the certain people from the first life using the interaction among the fellow being in their social language, especially their close family (Kridalaksana, 2009:26). In the 
Longman dictionary (2007:440) was defined that "mother tongue" (اللغة الأم) as first language which is acquired at home. But the "native language (اللغة الوطنية) (اللغة الأصلية) was defined as the language which a person acquires in early childhood because it is spoken in the family and/or it is the language of the country where he or she is living. The native language is often the first language a child acquires but there are exceptions. Children may, for instance, first acquire some knowledge of another language from a nurse or an older relative and only later on acquire a second one which they consider their native language. Sometimes, this term is used synonymously with "first language" (Longman Dictionary, 2007: 445-446). Thus, the connection line between the indigenous language and mother language can look at from the term "first language".

One of the way to preserving the mother language/ indigenous language is by doing research about the translation in the book of Islamic moral ethic which has the special characteristics, such as the model of translation in Javanese and Arabic language. By reading and elaborating the Javanese - Arabic language, both language in Asia (Arabic and Javanese) will be kept from becoming the dying language. It can be understood by looking at the "pattern of sentences" in the Javanese language, Arabic language, and Indonesian language. There is a beautiful diversity between languages in Asia. Crystal (2010) had been argued why the people should keep the language (why should we care). We should care the language because of some reasons, such as: (1) because we need diversity, (2) because languages express identity, (3) because languages are repositories of history, (4) because languages contribute to the sum of human knowledge, and the last reason (5) because languages are interesting in themselves. We can look at from this figure 1.

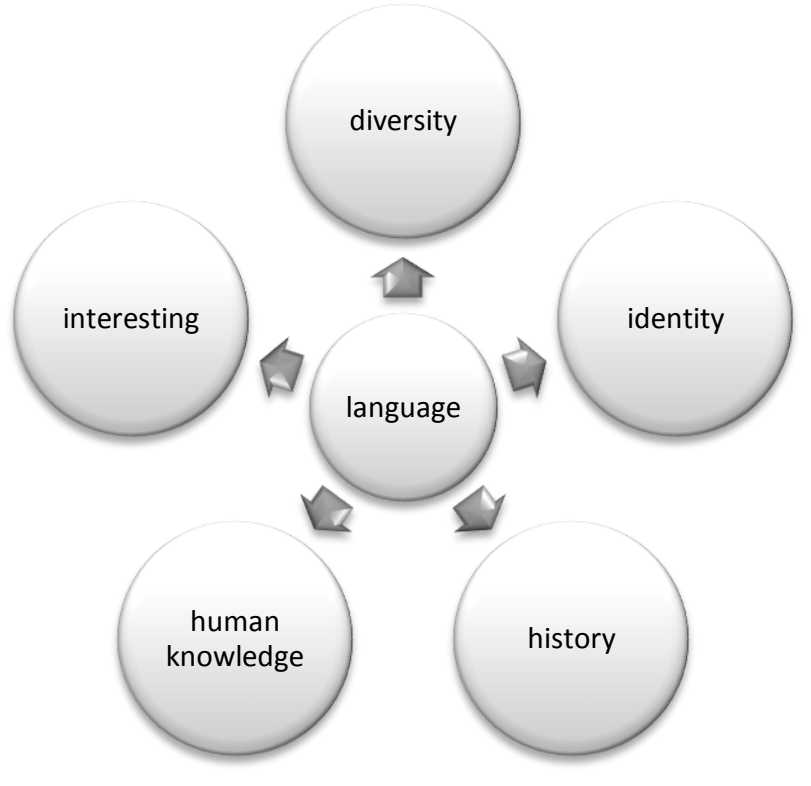

\section{Figure 1. the reasons how we should care the language?}

Crystal (2010:84) had concluded that there was a dying language, but in the other part of the world there is a new language growing. People are discovering new languages. An expedition travels to an isolated valley in the middle of the forest of Papua New Guinea and finds a small community living there. When they try to talk to the people, they realize that 
the language isn't like any of the others in the region. The world total of languages goes up by one. After looking at the discovering new languages, so the next problem is how to decide the different between "language" and "dialect". Language is made up of any dialects, and the people who speak those dialects generally understand each other (even if they do have the occasional difficulty with local accents or words).

Crystal had described that there was a sick language and health language. A sick language is a dying language. The language becomes dead because the speaker was dead. There are three ways to keep the language from dying, they are: speaking, writing, and signing. There are many languages in the world, especially in Asia, to empowering Asia, we should learn about the culture of Asia, learning the culture of Asia can be elaborated using the language. Asia has every known type of climate, from the polar to the tropical. The heart of the continent has extremes of temperature in winter and summer and low rainfall. The product of thousands of years of migrations, invasions, conquest and intermingling, the people of Asia belong mainly to three ethnic groups: Mongoloid (including Chinese, Japanese and Koreans), Caucasoid (including Arabs, Afghans, Iranians, Pakistanis and most Indian people) and Negroid (in parts of the Philippines and Shouth East Asia. A multitude of languages and dialects is spoken, derived from Indo-European, Altaic, Semitic, Sino-Tibetan and other language families. Asia was the birthplace of several religions. From this statement, we can conclude the urgency why we should know and care about Asia. This simple article tries to elaborate about one of the Islamic moral ethic books which had been translated by Arabic-Javanese language.

As we know that both languages are the famous language in Asia. Both languages also were better known by the public and scholars as a great connection interaction. Historically, the connection line between Javanese and Arabic language has been discovered from the manuscript and subsequently in books which appeared in the 19th century the common Javanese script is often used, but there are also a number of manuscript in Arabic script (Uhlenbeck, 1964:10). Doing research about Arabic and Javanese language is a same activity with reading the Asia. This article was undertaken to investigate the moral ethics learned in the Arabic-Javanese translation text, and how this model of translation can be the main aspect of protecting the indigenous/natural/mother language in Indonesia as a main potential of Asian Cultural Heritage. The purpose of this study was divided into two main parts, they are: (1) to elaborate and investigate the characteristics of Arabic Javanese translation in the book of Bidayatul-Hidayah, (2) to find the main aspects how the Arabic - Javanese translation in the moral ethic books can be the main aspect to preserve the indigenous language in Asia.

\section{METHOD}

The method in this research was divided into three parts, they are (1) collecting the data, (2) analysis the data, and (3) reporting the result of the research. The first step, collecting data had been used the observation method to the texts of Bidayatul-Hidayah, the text was translated from Arabic language to the Javanese language. The observation was started from the observation the pattern of the sentences in the Arabic language and then the translation model in Javanese language.

The kernel or basic sentence in Arabic is either (subject+ predicate or verb+ agent), such as /asy-syamsu chāriqatun/ (الثمس حارقة) 'the sun is burning. Furthermore, the verbal sentence in Arabic language consist of verb, always in first position, for example /yaktubūna/ (يكتبون) or 'they write'. Some of Arabic scholars had elaborated about the basic sentences and Arabic 
grammar comprehensively, the fenomenal one is Haywood (1965), under his book's title “A New Arabic Grammar of The Written Language". Then, the modern one, which has elaborated about the Arabic Grammar, especially Arabic sentences, such as: Ryding (2005), under his modern book "A Reference Grammar of Modern Standard Arabic.

Ba'albaki (1993:214) has defined a sentence in Arabic language as a referential unit including an information and a subject constituting the pillar of this sentence and rendering a useful meaning. Some supplements may be attached to the sentence; their purpose is to clarify the meaning and improve the speech. The sentence is also called useful composite speech and is divided into two kinds, verbal and nominal, for example /qāma Zaidun/ (زيام زيد) and IZaidun qāma/ (زيد قام).

The dominant pattern in the Arabic sentences is "nominal sentence" or jumlah ismiyyah. In his research, Anis (2014:245) had concluded that jumlah ismiyyah (Arabic Nominal Sentences) was a dominant pattern in the Arabic Newspaper Headlines, such as Al-Ahram and $a l$ Wafd Daily Newspaper. Except, in the imperative sentences, the headline was using the verbal sentences. In this case, to make an understandable way to elaborate both of the basic sentences in Arabic language, we will give some example of nominal sentences and verbal sentences in Arabic language. The kernel or basic sentence in Arabic is either (subject+ predicate or verb+ agent), such as /asy-syamsu chāriqatun/ (الثمس حارقة) 'the sun is burning. Furthermore, the verbal sentence in Arabic language consist of verb, always in first position, for example lyaktubūna/ (يكتبون) or 'they write'.

The analysis data will focus to the problems of the article, (1) to investigate the moral ethics learned in the Arabic-Javanese translation text can be observed by doing the descriptive qualitative data analysis in the texts book of Bidayatul Hidayah, and the second problems (2) how this model of translation can be the main aspect of protecting the indigenous/natural/mother language in Indonesia as a main potential of Asian Cultural Heritage can be analyzed by SWOT analysis, by looking at the strengthen (S), the weakness $(\mathrm{W})$, opportunity $(\mathrm{O})$, and the threat $(\mathrm{T})$ of Arabic - Javanese translation toward preserving the indigenous language in Asia. The findings, the results, and the suggestions from this research will be reported by formal and informal reporting. This research can be done by the PNBP UNS foundations 2016 at "the science and technology for the public society" or IbM (Iptek bagi Masyarakat) grants design of the public society dedication.

\section{FINDINGS AND DISCUSSION}

As we know that, translation can be defined as a certain activity. Nord (2001:1) had concluded that translating as a purposeful activity. It means that translation has a certain function or functions of texts and translation. This approach always called by Skopostheorie. From the book of Bidayatul-Hidayah written by Imam Al-Ghazali, we can defined the purpose of the texts and translation, how to rendering the message of Islamic moral ethic to the readers. In this part of finding and discussion will be divided into two main parts of solving problems data analysis, they are: (1) investigating the substance of Bidayatul Hidayah toward linguistics aspects and (2) the SWOT analysis how Arabic-Javanese translation ready to preserve the indigenous language in Asia.

\section{Investigating the Substances of Bidayatul-Hidayah toward Linguistics Aspects}

The translation as a purposeful activity makes the translator should care and pay attentions to the functions of the texts inside the process of translation, for example by 
looking at the units of the language deeply, in this case Arabic and Javanese language. Machali (2009) has emphasized the function of vocative and the function of aesthetic inside the process of translations. Vocative (النداء) (حالة النداء) is a noun phrase which is an optional part of a sentence, and which names or indicates one being addressed, for example: Really dear, do you think so? That's a pretty dress, Mrs. Johnson (Longman Dictionary, 2002:731).

As an Islamic moral ethic book and guideline to do the good character in the life, Bidayatul-Hidayah book has a mainstream and high field dominant to the vocative function texts. It can be looked from the pronoun (ضمير)/ka/ in the text of Bidayatul-Hidayah. Pronoun as a word which may replace a noun or noun phrase can be the main evidence to conclude the vocative function in the text 1 below.

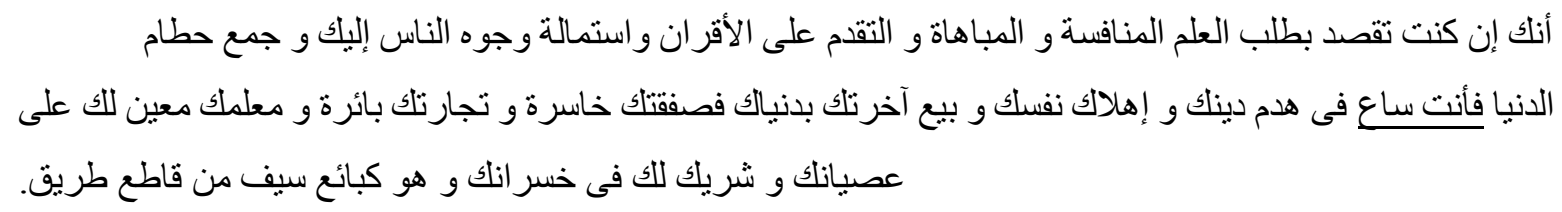

(Nashiruddin, 1964:9-10)

From the text 1 above, the translator had translated the pronoun /anta/ in the Arabic noun phrase "fa anta" into the Javanese language "mongko utawi siro" as the main evidence to gain the vocative function and the informative function in the text 1. Kridalaksana (2009:258) had matched this problem with the concept of "call" or "vocative". In the text 1 , the vocative form in Arabic language is /anta/ which had been used by Arabic Standard language as the second person masculine pronoun. The vocative was used to call the reader to gain the essences of the knowledge and sciences. The vocative form in the source language as seeing in the text 1 had been explicit by the translator with the target language explanation below.

"mangertiho, hei sedulur kang lagi demen banget lan maju inggone ngudi lan amrih ilmu"

(Nashiruddin, 1964:9).

In this case, we can look at that the translator stressed the statement of the ArabicJavanese translation text by the vocative forms. By looking the units of the language /anta/, "hei" (Javanese), and "sedulur" (Javanese) which have indicated a close relation between the translator and the reader of the book, we can conclude the style of the result of translation. The method of translation can be divided into two basic parts, (1) the tendency to the source language (Arabic), and (2) the tendency to the target language. In the book Bidayatul Hidayah, the method of translation was dominant into the target language. It means that the delivering message and substances of the book is very important. This fact can be looked from the model of technique of translation, word for word translation. We can look this model from the table 2.

Hatim and Munday (2004:11) had concluded that the split between form and content is linked in many ways to the major polar split which has marked the history of western translation theory for two thousand years, between two ways of translating 'literal' and 'free'. A literal model also described as "word for word" translation, which would serve as an aid to the reader who, it could be assumed, was acquainted with good sense or good manner with the source language. Four centuries later, St Jerome described his Bible translation strategy as 'I render not word for word but sense for sense'. This approach was of particular importance for the translation of such sensitive texts as the Bible, deemed by many to be the 
repository of truth and the word of God. The literal and free translation strategies can still be seen in texts to the present day.

Table 2 Arabic-Javanese Model of Word for Word Translation

\begin{tabular}{|c|c|c|}
\hline No. & Teks Sumber (Arab) & Teks Target (Jawa) \\
\hline 1 & 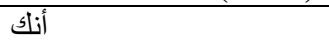 & Ing setuhune sira \\
\hline 2 & 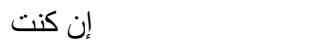 & Lamun ana sapa sira \\
\hline 3 & تقصد & Iku neja sira \\
\hline 4 & بطلب العلم & Kelawan olehe amrih ilmu \\
\hline 5 & المنافسة & $\overline{\text { Ing edi edi nane }}$ \\
\hline 6 & و المباهاة & Lan agung agung ngane \\
\hline 7 & و التقدم & $\overline{\text { Lan ing ngelancangi }}$ \\
\hline 8 & على & Ingatase \\
\hline 9 & الأقران & Piro - piro pantarane \\
\hline
\end{tabular}

\section{The SWOT Analysis to Preserve the Indigenous Language in Asia}

The Arabic - Javanese translation model should be strongly hold on toward the modernity era in order to preserve the existence of indigenous language in Asia, to fortify and to strengthen the quality of moral-ethic belongs to young generation of Indonesia nation. To face the modernity and to gain the empowerment of translation model in order to preserve the indigenous language in Asia, the Arabic-Javanese translation should care with the four items, such as: the strengths, a weakness, an opportunity, and a threat.

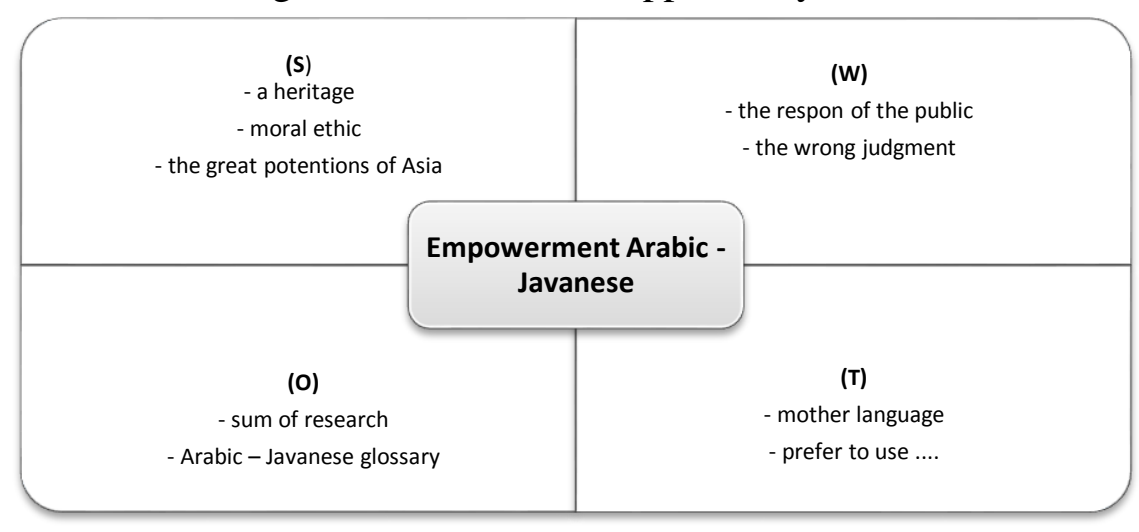

Figure 2. the SWOT analysis of Arabic Javanese Empowerment the Indigenous Language in Asia

The second problem is how the substance of moral ethic in the Arabic-Javanese translation can be the main aspect of preserving the indigenous language. It needs to the great attentions to: (1) the strengths, (2) the weaknesses, (3) the opportunities, and (4) the threats. For the strengths we should look at the fact about the potention of the nation as a heritage. Asia as a great continent also has many potentials, covering a number of language families that span the Asia continent and the great oceans that surround it (Yap, 2011:1).

The model of Arabic - Javanese translation using the pegon orthography is the biggest heritage for the academician to preserve it. Many muslim scholar using the Arabic - Javanese translation to transfer the moral ethic to the Javanese people. It means that the potention of 
the translation model is transfering the substance of moral ethic based on Islamic famous scholar, such as Imam Al-Ghazali.

The weaknesses are divided into two parts, (1) the respon of the public to ArabicJavanese translation model, and (2) the wrong judgment about old-fashioned model of Arabic-Javanese translation model in the modern era. The respon is correlated with the quality of understanding to the pegon orthography in Javanese language. Just a few people can read and write using the pegon orthography. The term of orthography is used for spelling in general and for correct or standard spelling, but in this case orthography is more likely to be used of alphabetic writing than of syllabic writing, and is unlikely to be used of ideographic writing (writing systems). But this weakness can be solved by the scholar to make a guide line for read and write using pegon writing system.

The opportunities how Arabic -Javanese translation in the book of Islamic moral ethic can face the globalization era are correlated with the ability of the modern scholar to get the sum of research about Arabic - Javanese translation until the substance of moral ethic can be delivered to the public to build the better life. The composing of Arabic - Javanese glossary also can be the main opportunities the process of empowering the Arabic Javanese translation. In this case, glossary of Arabic-Javanese can be defined as the brief dictionary and also the list of the lexicon in the certain field using the description.

The threats from the Arabic - Javanese translation to face the modernity are divided into two aspects. First, the Javanese as mother language or native language should prepare the challenges in the modernity. Many people prefer to use the English language, bahasa Indonesia, and Chinese language rather than the Javanese language. In fact, Javanese language as the indigenous language should be kept until everlasting. Crystal (2010:2) has remembered us that "for a language is really alive only as long as there is someone to speak it to". Not only to speak, but also to translate it.

\section{CONCLUSIONS AND SUGGESTIONS}

Hornberger (2008:1) has said "can schools save indigenous language? Policy and practice on four continents". The precarious circumstances of the world' indigenous languages are by now well known: of 6.800 languages currently spoken in the world, not only are more than half at risk of extinction by the end of this century, but approximately 95

per cent are spoken by less than five per cent of the world's population, mainly indigenous languages and speakers. It means that this is the big challenge and great defiance to the scholars and the academicians to save and preserve the existence of indigenous language.

Finally, we can conclude that by implementing the substance of the moral ethic book in this life, actually we can also preserve the existence of indigenous language in Asia, not only the language, but also the model and the way how to translate and rendering the substance of the book to the public. We can also conclude that the book of Bidayatul-Hidayah as a moral ethic book was very dominant with the vocative function and informative function. This fact also has been strengthening by the method of Arabic-Javanese translation which has mainstream to the target language (Javanese). This method can be concluded from the word for word model of translation in the book of Bidayatul-Hidayah. To preserve the indigenous languages in Asia and to gain the empowerment of translation model, the Arabic-Javanese translation should care with the four items, such as: strength, a weakness, an opportunity, and a threat. 


\section{REFERENCES}

Anis, M. Y.. 2014. "Konstruksi Tema Rema Judul Berita dalam Surat Kabar Al-Ahram: Analisis Sintaksis". Lisania Jurnal Ilmu dan Pendidikan Bahasa Arab, Jurusan Tarbiyah STAIN Salatiga. Vol. V/ No. 2/ 2014. Hal. 245-264.

Ba'albaki, R.M. 1993. Dictionary of Linguistic Terms English-Arabic. Beirut: Dar el-ilm lilmalayin

Crystal, D. 2010. A Little Book of Language. Australia: University of New South Wales Press Ltd (A UNSW Press book).

Haywood, J.A. and H.M. Nahmad. 1965. A New Arabic Grammar of The Written Language. London: Lund Humphries.

Hatim, B. and J. Munday. 2004. Translation an Advanced Resource Book. London: Routledge Taylor and Francis Group.

Hornberger, N. H. 2008. Can Schools Save Indigenous Languages? Policy and Practice on Four Continents. New York: Palgrave Macmillan.

Kridalaksana, H. 2009. Kamus Linguistik Edisi Keempat. Jakarta: PT Gramedia Pustaka Utama.

Longman Dictionary.2007. Longman dictionary of American English. England : Pearson Education Ltd

Machali, R. 2009. Pedoman bagi Penerjemah: Panduan Lengkap bagi Anda yang Ingin Menjadi Penerjemah Profesional. Bandung: Penerbit Kaifa.

Nāshiruddin, H. 1964. Bidāyatul Hidāyah. Kudus: Maktabah Manara.

Nord, C. 2001. Translating as a Purposeful Activity: Functionalist Approaches Explained. Manchester: ST Jerome Publishing.

Ryding, K. C. 2005. A Reference Grammar of Modern Standar Arabic. Cambridge: Cambridge University Press.

Uhlenbeck, E.M. 1964. A Critical Survey of Studies on the Languages of Java and Madura. Netherlands: The Hague.

Yap, F. H (ed). 2011. Nominalization in Asian Languages: Diachronic and Typological Perspective. Amsterdam: John Benjamins Publishing. 